\title{
Effect of Halophilic Bioformulations on Soil Fertility and Productivity of Salt Tolerant Varieties of Paddy in Sodic Soil
}

\author{
Ratna Sahay $^{1 *}$, A.K. Singh ${ }^{1}$, Sanjay Arora ${ }^{2}$, Archana Singh ${ }^{1}$, D.K. Tiwari ${ }^{1}$, \\ R.C. Maurya ${ }^{1}$, Vikash Chandra ${ }^{1}$ and Sunil Singh ${ }^{1}$ \\ ${ }^{1}$ ICAR-Krishi Vigyan Kendra, Unnao-229881 (UP), India \\ ${ }^{2}$ ICAR-Central Soil Salinity Research Institute, RRS, Lucknow-226002 (UP), India \\ *Corresponding author
}

\section{A B S T R A C T}

\begin{tabular}{|l|}
\hline Ke y w o r d s \\
Sodic soil, Halo- \\
Azo, Halo-PSB, \\
Salt tolerant rice \\
varieties
\end{tabular}

A field experiment was conducted during Kharif season of 2016-17, at the farmer's fields in village Munshikhera, district Unnao to study the efficacy of halophilic bio fertilizers, Halo Azotobacter (Halo-Azo) and Halo Phosphate Solubilising Bacteria (Halo-PSB) on the growth and productivity of salt tolerant variety of paddy (CSR-36) and residual fertility of post-harvest soil. It is observed that potential salt tolerant variety of paddy in association with halophilic beneficial microbes together can play a greater role to improve the productivity of paddy as well as soil fertility. These bioformulation showed significantly increased plant growth in terms of germination per cent, plant establishment per cent, plant height, no. of effective tillers/hill, no. of grains /Panicle, length of panicle, test weight grain and straw yield. Alone as well co-inoculation of Halo-Azo and Halo-PSB increased the productivity of CSR-36 significantly. Organic carbon, available nitrogen and available phosphorus content increased up to $20,9.9$ and $16.8 \%$ respectively with the inoculation of halophilic bioformulations. Exploitation of azotobacter and phosphate solubilising bacteria as bio fertilization has enormous potential in improving the crop productivity and soil fertility in sodic soil condition.

\section{Introduction}

Salinity and sodicity of soil is occurring as global problem that extends across all continents in more than 100 countries of the world. Salt affected lands are estimated at about 955 million ha world-wide (Szabolcs, 1994), afflicting 7\% of the world's total arable land (Flowers et al., 1997). Soil sodicity is one of the most adverse environmental factors responsible for limiting the productivity of crop plants. It is a very serious problem in many part of the world causing considerable loss in agriculture production. The main reasons for development of soil salinity are natural processes or crop irrigation with saline water. The major reasons for low productivity of crops grown on salt-affected soil are the salt toxicity, poor soil physical properties and fertility problems that adversely affect the growth and yield of most crops (Curtin and Naidu 1998; Grattan and Grieve 1999; Gao et al., 2008). The reclamation of saline-sodic soils is one of the main problems for humans 
in the future (Szabolcs 1994) throughout the world. The reclamation of sodic soils requires additional agricultural inputs and practices like amendments, water and infrastructure for drainage, which is cost effective and resource consuming. An alternate approach for the utilization of salt affected soils is growing salt tolerant varieties of different crop species capable of performing in such conditions to produce an economic yield as well as improve the soil fertility (Sahay and Patra, 2014).

Rice is an essential and most important cereal crop. Grain yield of rice is much lower in salt affected soils because of its sensitivity to salt stress (Gao et al., 2007; Ismail et al., 2007). But this crop is recommended as the first crop for the reclamation of sodic soils and preferred during initial years after reclamation due to certain adaptive reasons (Chhabra and Abrol, 1977). Productivity of rice in salt affected soil can be enhanced through the use of salt tolerant varieties with proper agronomic practices (Singh et al., 2016). However, complementing the reclamation technology with salt tolerant high yielding and suitable rice varieties holds great promise and has delivered lot of dividends and impact under such conditions (Singh et al., 2004; CSSRI, 2006; Gautam et al., 2010).

Sodic soils are inherently low in organic matter, available Nitrogen and Phosphorus. These soils are more prone to $\mathrm{N}$ losses due to higher $\mathrm{N}$ volatilization caused by high $\mathrm{pH}$, further aggravating $\mathrm{N}$ deficiency. Microbial activity, which influences $\mathrm{N}$ mineralization, is restricted by salt stress (Abrol et al., 1988; Liu and Kang, 2014; Wong et al., 2010). Other than nitrogen soluble $\mathrm{P}$ is often the limiting mineral nutrient for biomass production (Hameeda et al., 2006). Plants utilize fewer amounts of phosphate fertilizers that are applied and the rest is rapidly converted into insoluble complexes in the soil. Introduction of effective halophilic bioformulation increase the availability of nutrients in such adverse soil conditions. These bioformulations play a greater role with salt tolerant varieties and further improve the crop produce and soil fertility. Several researchers reported that introduction of these microbes are found very effective in salt affected soils to improve the crop productivity, quality of produce and soil properties (Kumar et al., 2014; Sahay And Patra, 2013). Salt tolerant high yielding varieties with halophilic bioformulation can play a greater role in such soil conditions to improve the crop productivity and soil fertility as well.

\section{Materials and Methods}

A field experiment was conducted during the kharif season of 2017 at the village Munshikhera of Unnao, India to study the impact of two halophilic bioformulations, halophilic azotobacter (Halo-Azo) and halophilic phosphate solubilizing bacteria (Halo-PSB) with effective salt tolerant variety of rice (CSR 36) on crop productivity and soil fertility in sodic soil. Soil of the experimental site was sodic in nature with $\mathrm{pH} 8.8$, Electrical Conductivity $0.26 \mathrm{dS} / \mathrm{m}$, exchangeable Sodium percent about 26, Organic Carbon (0.18\%), Available Nitrogen (160 kg/ha), available Phosphorus (17.2kg/ha), and Potassium (256 $\mathrm{kg} / \mathrm{ha}$ ). The experiment was conducted with five replications and four treatments consisting of control $\left(\mathrm{T}_{1}\right)$, inoculation with Halo-Azo $\left(\mathrm{T}_{2}\right)$, inoculation with Halo- PSB $\left(\mathrm{T}_{3}\right)$ and inoculation with both of bio formulation (Halo-Azo + Halo-PSB) $\left(\mathrm{T}_{4}\right)$ in randomized block design (RBD). The efficiency of halophilic bioformulation was evaluated in terms of germination percentage, plant establishment percent, productivity of crop and soil fertility in terms of available nitrogen and available phosphorus in postharvest soil. The certified seeds of paddy (CSR 36) and halophilic bioformulations were procured from Central Soil Salinity Research 
Institute, Regional Research Station Lucknow. Soil samples from each treatment was collected and analyzed for $\mathrm{pH}$, electrical conductivity (EC), Organic carbon (Walkely and Black, 1934), available nitrogen (Subbiah and Asija, 1956) and phosphorus (Olsen et al., 1954). Rice seeds were soaked in bioformulation solutions before nursery sowing according to different treatments. The nursery for the trials was grown in first week of June. One month old rice seedling roots were again treated with same bioformulations before transplantation. The grain and straw yield data were recorded at harvest. The data was subjected to analysis of variance (ANOVA) and least significant differences (LSD) were calculated using the F-method (Sokal and Rohlf, 1981).

\section{Results and Discussion}

Different growth parameters viz. germination per cent, plant establishment per cent, plant height, no. of effective tillers/hill, no. of grains /Panicle, length of panicle, test weight grain and straw yield were significantly promoted by the inoculation of bioformulations (Table 1). Salinity is one of the environmental factors that have a critical influence on the germination of seeds and plant establishment (William et al., 1998). Inoculation of bioformulations improves the germination per cent ranged from 10 to 16 per cent as compare to control. Germination per cent, plant establishment per cent, number of effective tillers per hill, number of grains per panicles, test weight and grain yield were recorded 1.4, $1.5,1.75,2.21,1.1$ and $3.6 \%$ respectively higher with inoculation of Halo-PSB than Halo-Azo. Co-inoculation treatment of HaloAzo and Halo-PSB significantly improved the all growth parameter recorded as compare to control. Co-inoculation treatment of both bioformulation significantly increased the germination per cent, plant establishment per cent and grain yield as compare to alone inoculation of Halo-Azo and Halo-PSB.

The increase in grain yield was $8.5,12.5$ and $18.0 \%$ over control, by the inoculation with bioformulations, viz. Halo-Azo, Halo-PSB and Halo-Azo + Halo-PSB respectively. Inoculation of bioformulation also increased the straw yield of crop up to $11.6 \%$ as compared to control. Rice is exceptionally sensitive to salinity and sodicity at early seedling stage (Aslam et al., 1988, 1993) and high yield losses have been observed because of high mortality and poor crop establishment. Bioformulation treatments enhance the germination and crop establishment up to 19.3 and 13.1 per cent respectively, which ultimately helps to improve in grain and straw yield of crop.

Chemical analysis of post-harvest soil showed significant response of bioformulation on residual fertility of soil (Table 2).

Table.1 Effect of bioformulation on different growth parameters of Paddy crop

\begin{tabular}{|c|c|c|c|c|c|c|c|c|c|}
\hline$T^{*}$ & $\begin{array}{l}\mathbf{G}^{\%} \\
(\%)\end{array}$ & $\begin{array}{c}\text { Plant } \\
\text { Establishment } \\
(\%)\end{array}$ & $\begin{array}{l}\text { Plant } \\
\text { height } \\
(\mathrm{cm})\end{array}$ & $\begin{array}{l}\text { No. of } \\
\text { effective } \\
\text { tillers/hill }\end{array}$ & $\begin{array}{l}\text { No. of } \\
\text { grains } \\
\text { /Panicle }\end{array}$ & $\begin{array}{l}\text { Length of } \\
\text { panicle } \\
\text { (cm) }\end{array}$ & $\begin{array}{c}\text { Test } \\
\text { weight } \\
\text { (g) }\end{array}$ & $\begin{array}{l}\text { Grain } \\
\text { Yield } \\
\text { (qt/ha) }\end{array}$ & $\begin{array}{c}\text { Straw } \\
\text { yield } \\
\text { (qt/ha) }\end{array}$ \\
\hline$T_{1}$ & 80.6 & 85.6 & 113.9 & 11.0 & 129 & 25.8 & 26.1 & 40.0 & 60.4 \\
\hline$T_{2}$ & 90.8 & 91.2 & 115.7 & 11.4 & 136 & 28.3 & 26.9 & 43.4 & 65.3 \\
\hline$T_{3}$ & 92.1 & 92.7 & 114.2 & 11.6 & 139 & 28.1 & 27.2 & 45.0 & 64.3 \\
\hline $\mathrm{T}_{4}$ & 96.2 & 96.8 & 116.3 & 11.8 & 142 & 29.5 & 28.1 & 47.2 & 67.4 \\
\hline LSD $_{0.05}$ & 1.5 & 1.9 & 2.5 & 0.6 & 6.5 & 2.8 & 1.8 & 1.8 & 3.1 \\
\hline
\end{tabular}


Table.2 Effect of bioformulation on residual fertility of soil

\begin{tabular}{|c|c|c|c|}
\hline $\mathrm{T}$ & OC $(\%)$ & A vailable $\mathbf{N}(\mathrm{kg} / \mathrm{ha})$ & A vailable P(kg/ha) \\
\hline $\mathrm{T}_{1}$ & 0.20 & 163.04 & 18.18 \\
\hline $\mathrm{T}_{2}$ & 0.23 & 178.12 & 18.90 \\
\hline $\mathrm{T}_{3}$ & 0.21 & 165.08 & 20.04 \\
\hline $\mathrm{T}_{4}$ & 0.24 & 179.26 & 21.24 \\
\hline $\mathrm{LSD}_{0.05}$ & 0.02 & 2.9 & 1.3 \\
\hline
\end{tabular}

Organic carbon, available nitrogen and available phosphorus content increase up to 20, 9.9 and $16.8 \%$ respectively with the inoculation of halophilic bioformulations. We have found that organic carbon content was significantly higher in all bioformulation inoculated treatments.

Bioformulation Halo-Azo strain significantly increased the $\mathrm{N}$ content of post-harvest soil either alone or in combination with HaloPSB. Available phosphorus content of soil was observed significantly higher in all PSB inoculated treatments.

The present study showed that crop productivity and soil fertility significantly enhanced by the inoculation with halophilic bioformulation with salt tolerant varieties. There have been a number of reports on plant growth promotion by the inoculation with halophilic strains in sodic soils (Singh et al., 2010). Sodic soils are deficient in many nutrients particularly $\mathrm{P}, \mathrm{N}$ and essential micronutrients. Bioformulations acidify the plant rhizosphere and enhance the availability of several nutrients (Sahay and Patra, 2014). The increase in nutrient availability plays an important role in increasing the crop production.

Exploitation of halophilic bioformulations as biofertilizer with salt tolerant verities of rice has enormous potential in utilization of unfertile sodic land for food security, environmental health and economic welfare of farmers.

\section{References}

Abrol, I.P., Yadav, J.S.P., Masood, F.I., 1988. Salt affected soils and thei rmanagement. FAO Soils Bull., 39, 119.

Aslam, M., Qureshi, R.H., Ahmad, N., 1993. Mechanism of salinity tolerance in rice (Oryza sativa L.). In: Leith, H., Massoum, A.A. (Eds.), Towards the Rational Use of High Salinity Tolerant Plants. Kluwer Academic Publisher, Netherlands, pp.135-138.

Aslam, M., Qureshi, R.H., Ahmad, N., Muhammad, S., 1988. Response of rice to salinity shocks at various growth stages and type of salinity in the rooting medium. Pak. J. Agric. Sci., 25, 199205.

Chhabra, R., Abrol, I. P. 1977. Reclaiming effect of rice grown in sodic soils. Soil Sci., 124:49-55.

CSSRI. 2006. CSSRI: A Journey to Excellence (1969-2006), Central Soil Salinity Research Institute Karnal India. P. 156.

Curtin D., Naidu R. 1998. Fertility constraints to plant production. In: Sumner M.E., Naidu R. (eds): Sodic Soil: Distribution, Management and Environmental Consequences. Oxford University Press, New York, 107-123.

Flowers, T.J., Garcia, A., Koyama, M., Yeo, A.R., 1997. Breeding of salt tolerance in crop plants - the role of molecular biology. Acta Physiol. Plant, 19, 427433. 
Gao S., Ouyang C., Wang S., Xu Y., Tang L., Chen F. 2008. Effects of salt stress on growth, antioxidant enzyme and phenylalanine ammonia-lyase activities in Jatropha curcas L. seedlings. Plant, Soil and Environment, 54: 374-381.

Gao, J.P., Chao, D.Y., Lin, H.X., 2007. Understanding abiotic stress tolerance mechanisms: recent studies on stress response in rice. J. Integr. Plant Biol., 49,742-750.

Gautam, R.K., Singh, R.K., Mishra, B., Verma, V., Ali, S. 2010. Collection, evaluation and utilization of rice genetic resources for salt tolerance by Central Soil Salinity Research Institute in India. In: S.D. Sharma (ed.), Genetic Resources of Rice in India: Past and Present. Today and Tomorrow's Printers and Publishers, New Delhi. pp. 229277.

Grattan S.R., Grieve, C.M. 1999. Salinitymineral nutrient relations in horticultural crops. Science Horticulture, 78: 127-157.

Hameeda, B., Harmi, G., Rupela, O.P., Wani, S.P., Reddy,G. 2006. Growth promotion of maize by phosphate solubilizing bacterial isolate from composts and macrofauna. Microbiol, 59: 23-147.

Ismail, A.M., Heuer, S., Thomson, M.J., Wissuwa, M., 2007. Genetic and genomic approaches to develop rice germplasm for problem soils. Plant Mol. Biol. 65,547-570.

Kumar, R., Shanthy, S., Kalaiarasi, A., Sumaya, M, 2014. The biofertilizer Effect of Halophilic phosphate solubilizing bacteria on Oryza sativa. Middle-East J. of Sci. Res., 19(10), 1406-1411.

Liu, S.H., Kang, Y.H., 2014. Changes of soil microbial characteristics in salinesodics oils under drip irrigation. J. Soil Sci. Plant Nutr., 14, 139-150.
Sahay, R., Patra, D.D., 2013. Identification and performance of stress tolerant phosphate solubilizing bacterial isolates on Tagetes minuta grown in sodic soil. Soil Use Mgt., 29, 494-500

Sahay, R., Patra, D.D., 2014. Identification and performance of sodicity tolerant phosphate solubilizing bacterial isolates on Ocimum basilicum in sodic soil. Ecological Engineering, 71, 639-643

Singh RK, Singh KN, Mishra B, Sharma SK, Tyagi NK (2004). Harnessing plant salt tolerance for overcoming sodicity constraints: an Indian experience. In: Advances in Sodic Land Reclamation. International Conference on Sustainable Management of Sodic Lands held at Lucknow, India during Feb 9-14, 2004. pp. 81-120.

Singh, A.V., Shah, S., Prasad, B., 2010. Effect of phosphate solubilizing bacteria on plant growth promotion and nodulation in soyabean (Glycine max (L.) Merr.) J. Hill agric., 1, 35-39.

Singh, Y.P., Mishra, V.K., Singh, S., Sharma, D.K., Singh, D., Singh U.S., Singh R.K., Haefele S.M., Ismail A.M.2016. Productivity of sodic soils can be enhanced through the use of salt tolerant rice varieties and proper agronomic practices. Field Crops Research., 190, 82-90.

Sokal, R.R., Rohalf, F.J., 1981. Biometry: The principals and Practices Statistics in Biological Research. Second ed. Freeman, New York, NY.

Subbiah, B.V., Asija, G.L., 1956. A rapid procedure for the determination of available nitrogen in soils. Curr. Sci., 22, 259-260.

Szabolcs, I., 1994. Prospects of soil salinity for the $21^{\text {st }}$ century. In: 15thWorldCongress of Soil Science, Acapulco, 10-16 July 1994, pp. 123141. 
Walkley, A., Black, L.A., 1934. An examination of detergent method for determining soil organic matter and a proposed modification of chromic and titration method. Soil Sci., 37, 29-38.

William J.K., Irwani A. U., John P.M., 1998. Effect of Salinity on Germination and
Seedling Growth of two Atriplex species (Chenopodiaceae). Annals of Botany, 82, 167-175

Wong, V.N.L., Greene, R.S.B., Dalal, R.C., Murphy, B.W., 2010. Soil carbon dynamics in saline and sodic soils: a review. Soil Use Manag., 26, 2-11.

\section{How to cite this article:}

Ratna Sahay, A.K. Singh, Sanjay Arora, Archana Singh, D.K. Tiwari, R.C. Maurya, Vikash Chandra and Sunil Singh. 2018. Effect of Halophilic Bioformulations on Soil Fertility and Productivity of Salt Tolerant Varieties of Paddy in Sodic Soil. Int.J.Curr.Microbiol.App.Sci. 7(09): 1174-1179. doi: https://doi.org/10.20546/ijcmas.2018.709.139 